\title{
DETERMINAN FAKTOR YANG BERHUBUNGAN DENGAN PENGETAHUAN PERAWAT DALAM PERAWATAN PALIATIF
}

Dwi Eri Retno Widowati, Retno Indarwati, Rista Fauziningtyas

Fakultas Keperawatan, Universitas Airlangga, Surabaya, Indonesia

\begin{abstract}
ABSTRAK
Pendahuluan: Di Indonesia hanya ada beberapa institusi pelayanan kesehatan yang telah melaksanakan perawatan paliatif. Hal ini terkait dengan pengetahuan para tenaga kesehatan yang berperan dalam pelayanan perawatan paliatif. Tujuan dari penelitian ini adalah untuk mengetahui determinan faktor yang berhubungan dengan pengetahuan perawat dalam perawatan paliatif di RSUD Dr. Soetomo.

Metode: Penelitian ini menggunakan desain cross-sectional. Total sampel sebanyak 115 responden menggunakan teknik total sampling. Variabel independen dalam penelitian ini adalah usia, pendidikan, pengalaman mengikuti pelatihan, lama bekerja, dan jenjang karir, sedangkan variabel dependennya yaitu pengetahuan perawat dalam perawatan paliatif. Data didapatkan dengan kuesioner PCQN dan dianalisis dengan mengguanakan spearman's rho, dan regresi ordinal.

Hasil: terdapat hubungan antara usia $(p=0,004)$ dan lama bekerja $(p=0,016)$ dengan pengetahuan perawat dalam perawatan paliatif.

Kesimpulan: Usia, lama bekerja, pengalaman mengiktui pelatihan dapat meningkatkan pengetahuan perawat. Diharapkan kepada perawat yang ada di RSUD Dr. Soetomo dapat mengikuti pelatihan agar pengetahuan yang didapat terus bertambah serta peneliti selanjutnya dapat mengidentifikasi tentang praktik perawat dalam melaksanakan perawatan paliatif serta dengan jumlah responden yang lebih besar.
\end{abstract}

Kata Kunci: perawatan paliatif, pengetahuan, perawat

\begin{abstract}
Introduction: There are only a number of health care institutions in Indonesia that have carried out palliative care. This is related to knowledge of health workers who work in palliative care services. The aim of this study to find out determinants of factors that related to nurses' knowledge in palliative care at RSUD Dr. Soetomo.

Method: This study used a cross-sectional design. The total sample was 115 respondents using total sampling technique. The independent variables in this study were age, education, training experience, length of work, and career leader, and the dependent variables were knowledge of nurses in palliative care. Data were obtained by PCQN questionnaire and analyzed by using spearman rho, and ordinal regression.

Result: There was relationship between age $(p=0.004)$ and length of work $(p=0.016)$ with knowledge in palliative care.

Conclusion: Age, length of work, training experience can increase nurses knowledge. It is expected that nurses at RSUD Dr. Soetomo can take part in the training so that the knowledge gained will increase and the next researcher can identify the practice of nurses in carrying out palliative care and do with a larger number of respondents.
\end{abstract}

Keywords: palliative care, knowledge, nurse 


\section{PENDAHULUAN}

WHO (World Health Organization) telah menetapkan penyakit apa saja yang tergolong dalam kategori paliatif dan telah terdapat prinsip-prinsip dasar untuk pelayanan perawatan paliatif yang berkualitas. Hal ini membuat perawat harus memiliki pengetahuan yang mendukung dalam pelaksanaan perawatan paliatif yang adekuat ${ }^{[1]}$. Namun data empiris tentang implementasi praktek ini belum ditemukan di Indonesia walaupun perawatan paliatif sudah diimplementasikan oleh beberapa rumah sakit rujukan dan telah ada undangundang yang mengaturnya.

Lebih dari 40 juta orang di dunia membutuhkan perawatan paliatif, hanya saja baru $14 \%$ yang memperoleh perawatan paliatif. Mayoritas masyarakat yang membutuhkan perawatan tersebut berada pada usia lebih dari 60 tahun (lansia) ${ }^{[2],[3]}$.

Data Riset Kesehatan Dasar tahun 2018 menyatakan perawatan paliatif yang diselenggarakan di Indonesia pada saat ini lebih menekankan pada penyakit kanker dan HIV/AIDS karena adanya peningkatan yang signifikan dari kasus tersebut dalam setiap tahunnya. Pravalensi kanker di Indonesia mencapai 1,79 per 1000 penduduk, naik dari tahun 2013 sebanyak 1,4 per 1000 penduduk $^{[4] .}$

RSUD Dr. Soetomo merupakan tempat lahirnya perawatan paliatif di Indonesia ${ }^{[5]}$. Perawatan paliatif yang diberikan di RSUD Dr. Soetomo berupa perawatan paliatif rawat jalan (poliklinik), rawat inap, rawat rumah (homecare), day care, dan respite care. Pasien paliatif yang menjalani rawat inap di RSUD Dr. Soetomo ditempatkan di ruangan tergantung pada primary site tumornya ${ }^{[5]}$. Sehingga ada kolaborasi antara dokter paliatif dan dokter penanggung jawab pasien (DPJP) dan tenaga medis di setiap ruangan yang termasuk dalam irna medik.

Perawatan paliatif yang dilakukan oleh perawat dipengaruhi oleh beberapa faktor. Dalam sebuah penelitian menyatakan bahwa terdapat beberapa perawat yang tidak memiliki pengetahuan cukup tentang perawatan paliatif, namun perawat yang menerima pendidikan tentang perawatan paliatif mengganggap bahwa pendidikan yang mereka terima tidak mencukupi ${ }^{[6]}$. Tingkat pendidikan akan mempengaruhi tingkat pengetahuan seseorang dalam memahami informasi kesehatan ${ }^{[7]}$. Oleh sebab itu peneliti ingin untuk meneliti faktor apa saja yang berhubungan dengan pengetahuan perawat dalam perawatan paliatif, sehingga nantinya dapat dimanfaatkan dalam meningkatkan mutu asuhan keperawatan dengan memperhatikan faktor-faktor yang berkaitan.

\section{METOLOGI PENELITIAN}

Desain penelitian yang digunakan dalam penelitian ini adalah deskriptif dengan pendekatan cross sectional. Populasi dalam penelitian ini adalah perawat RSUD Dr. Soetomo yang telah merawat pasien paliatif dalam enam bulan terakhir dan memiliki pendidikan minimal D3 Keperawatan Jumlah responden yaitu sebnyak 115 perawat diambil dengan teknik total sampling. Penelitian dilakukan selama bulan Mei 2019.

Variabel independen dalam penelitian ini adalah usia, pendidikan, pengalaman mengikuti pelatihan, jenjang karir dan lama bekerja. Variabel dependen penelitian ini adalah pengetahuan perawat dalam perawatan paliatif.

Kuesioner yang digunakan dalam penelitian ini yaitu PCQN. Palliative Care Quiz for Nurses (PCQN) merupakan keusioner untuk mengukur pengetahuan perawat dalam perawatan paliatif. Kuesioner ini mencakup tiga kategori konten utama: empat item tentang filosofi dan prinsip perawatan paliatif $(1,9,12,17), 13$ item pada penanganan nyeri dan gejala lainnya $(2$, $3,4,6,7,8,10,13,14,15,16,18,20$ ), dan tiga item pada aspek psikososial perawatan EOL $(5,11,19)$. Setiap item bisa dijawab: Benar, Salah, atau Tidak Tahu.

Instrumen ini menggunakan pertanyaan dengan jawaban "Benar", "Salah" dan "Tidak Tahu". Jawaban yang benar akan mendapatkan nilai 1dan 0 untuk setiap jawaban yang salah 
atau tidak menjawab. Rentang skor yaitu $0-20$. Skor yang tinggi menunjukkan kecenderungan responden memiliki pengetahuan yang lebih baik dalam perawatan paliatif.

Hasil pengukuran pengetahuan dapat dikelompokkan menjadi tiga kategori yaitu baik $(76 \%-100 \%)$, cukup $(56 \%-75 \%) m$ dam kurang ( $\leq 55 \%)$. Hasil ukur baik yaitu dengan mengalikan presentasi dan jumlah skor, sehingga $76 \% \times 20=15,2$ (digenapkan 15) sampai 20, begitu juga dengan cukup yaitu $56 \%$ × $20=11,2$ (digenapkan 11) sampai 14 , serta kategori kurang yaitu $0-11$. Sehingga dapat dikategorikan pengetahuan kurang apabila didapatkan skor 15-20, pengetahuan cukup yaitu 11-14 dan pengetahuan kurang dengan skr $0-10^{[8]}$.

Data dianalisis menggunakan uji korelasi spearman dengan sigifikansi $\rho<0,05$. Pada analisis multivariat menggunakan analisis uji regresi logistik berganda untuk mengetahui variabel independen mana yang berhubungan dengan variabel dependen.

Penelitian ini telah mendapatkan persetujuan etik Fakultas Keperawatan Universitas Airlangga dengan nomor sertifikat 1380-KEPK. Setiap responden menandatangani lembar informasi sebelum menjawab kuesioner. Para responden diberi nama samara untuk mempertahankan anonimitas mereka. Semua data mereka hanya peneliti yang mengetahui.

\section{HASIL}

Hasil penelitian menunjukkan bahwa mayoritas responden berusia 2635 tahun (usia dewasa awal) sebanyak 53 orang $(46,1 \%)$. Dilihat dari segi pendidikan, 73 responden (63,5\%) berpendidikan D3. Mayoritas responden pernah mengikuti pelatihan tentang perawatan paliatif, yaitu sebanyak 59 responden $(51,3 \%)$. Sebagian besar responden bekerja sebagai perawat di RSUD Dr. Soetomo selama lebih dari 10 tahun yaitu sebanyak 56 responden $(48,7 \%)$. Selain itu sebanyak 51 responden $(44,3 \%)$ jenjang karirnya yaitu PK 1.

Tabel 2 menunjukkan bahwa terdapat hubungann antara usia dan lama bekerja dengan pengetahuan perawat dalam perawatan paliatif. Sedangkan pada pendidikan, pelatihan dan jenjang kerja tidak berhubungan dengan pengetahuan perawat dalam perawatan paliatif. Pada tabel 2 dapat diketahui bahwa mayoritas perawat berusia 26-35 dengan lama bekerja $>10$ tahun memiliki pengetahuan dalam kategori kurang tentang perawatan paliatif. Usia di ukur menggunakan uji statistik Spearman's Rho, didapatkan hasil terdapat hubungan yang signifikan $(p=0,004)$ antara usia dengan pengetahuan perawat dalam perawatan paliatif. Selain itu juga menunjukkan tingkah korelasi lemah $(r=0,266)$ serta koefisien korelasi positif yang menunjukkan hubungan antara kedua variabel searah. Sedangkan lama bekerja diukur menggunakan uji statistik Spearman's Rho, didapatkan hasil terdapat hubungan $(p=0,016)$ antara lama bekerja dengan pengetahuan perawat tentang perawatan paliatif. Selain itu juga menunjukkan tingkah korelasi lemah $(r=0,225)$ serta koefisien korelasi positif yang menunjukkan hubungan antara kedua variabel searah.

Tabel 1 Distribusi karakteristik demografi responden determinan faktor yang berhubungan dengan pengetahuan perawat dalam perawatan paliatif di RSUD Dr. Soetomo

\begin{tabular}{ccccc}
\hline No & $\begin{array}{c}\text { Karakteristik } \\
\text { Demografi } \\
\text { Responden }\end{array}$ & Kategori & Frekuensi & Prosentase \\
\hline 1 & Usia & $17-25$ tahun & 4 & \\
\cline { 3 - 5 } & & $26-35$ tahun & 53 & 3,5 \\
\cline { 3 - 5 } & & $36-45$ tahun & 27 & 23,1 \\
\cline { 2 - 4 } & & $46-55$ tahun & 20 & 17,4 \\
\cline { 3 - 5 } & & $56-65$ tahun & 11 & 9,6 \\
\hline & & $\mathbf{1 1 5}$ & $\mathbf{1 0 0}$ \\
\hline
\end{tabular}


E - ISSN : $2722-127 X$

$P-I S S N: 2338-4700$

\begin{tabular}{|c|c|c|c|c|}
\hline \multirow[t]{4}{*}{2} & \multirow{3}{*}{ Pendidikan } & D3 & 73 & 63,5 \\
\hline & & S1 & 41 & 35,7 \\
\hline & & S2/Spesialis & 1 & 0,9 \\
\hline & \multicolumn{2}{|c|}{ Total } & 115 & 100 \\
\hline \multirow[t]{3}{*}{3} & \multirow{2}{*}{$\begin{array}{c}\text { Pengalaman } \\
\text { mengikuti pelatihan }\end{array}$} & $\mathrm{Ya}$ & 59 & 51,3 \\
\hline & & Tidak & 56 & 48,7 \\
\hline & \multicolumn{2}{|c|}{ Total } & 115 & 100 \\
\hline \multirow[t]{6}{*}{4} & \multirow[t]{5}{*}{ Lama Bekerja } & $6-12$ bulan & 1 & 0,9 \\
\hline & & 1-3 tahun & 7 & 6,1 \\
\hline & & $3-5$ tahun & 13 & 11,3 \\
\hline & & 5-10 tahun & 38 & 33,0 \\
\hline & & $>10$ tahun & 56 & 48,7 \\
\hline & Tota & & 115 & 100 \\
\hline \multirow[t]{5}{*}{5} & \multirow[t]{4}{*}{ Jenjang Karir } & PK 1 & 51 & 44,3 \\
\hline & & PK 2 & 40 & 34,8 \\
\hline & & PK 3 & 23 & 20,0 \\
\hline & & PK 4 & 1 & 0,9 \\
\hline & Total & & 115 & 100 \\
\hline
\end{tabular}

Tabel 2 Hubungan antara usia, pendidikan, pelatihan, lama kerja dan jenjang kerja dengan pengetahuan perawat dalam perawatan paliatif di RSUD Dr. Soetomo

\begin{tabular}{|c|c|c|c|c|c|c|c|c|c|c|c|}
\hline \multirow{3}{*}{$\begin{array}{c}\text { Variabel } \\
\text { Independe } \\
n\end{array}$} & \multirow[t]{3}{*}{ Kategori } & \multicolumn{6}{|c|}{ Pengetahuan } & \multirow{2}{*}{\multicolumn{2}{|c|}{ Total }} & \multirow{3}{*}{$\begin{array}{c}p \\
\text { value }\end{array}$} & \multirow[t]{3}{*}{$\mathbf{r}$} \\
\hline & & \multicolumn{2}{|c|}{ Kurang } & \multicolumn{2}{|c|}{ Cukup } & \multicolumn{2}{|c|}{ Baik } & & & & \\
\hline & & $f$ & $\%$ & $f$ & $\%$ & $f$ & $\%$ & $\bar{\Sigma}$ & $\%$ & & \\
\hline \multirow[t]{6}{*}{ *Usia } & 17-25 tahun & 4 & 3,5 & 0 & 0 & 0 & 0 & 4 & 3,5 & 0,004 & 0,266 \\
\hline & 26-35 tahun & 52 & 45,2 & 1 & 0,9 & 0 & 0 & 53 & 46,1 & & \\
\hline & $36-45$ tahun & 23 & 20 & 3 & 2,6 & 1 & 0,9 & 27 & 23,5 & & \\
\hline & $46-55$ tahun & 17 & 14,8 & 3 & 2,6 & 0 & 0 & 20 & 17,4 & & \\
\hline & 56-65 tahun & 9 & 7,8 & 2 & 1,7 & 0 & 0 & 11 & 9,6 & & \\
\hline & Total & 105 & 91,3 & 9 & 7,8 & 1 & 0,9 & 115 & 100 & & \\
\hline \multirow[t]{4}{*}{ Pendidikan } & D3 & 65 & 56,5 & 7 & 6,1 & 1 & 0,9 & 73 & 63,5 & 0,955 & $-0,005$ \\
\hline & S1 & 39 & 33.9 & 2 & 1.7 & 0 & 0 & 41 & 35,7 & & \\
\hline & S2 & 1 & 0,9 & 0 & 0 & 0 & 0 & 1 & 0,9 & & \\
\hline & Total & 105 & 91,3 & 9 & 7,8 & 1 & 0,9 & 115 & 100 & & \\
\hline \multirow{3}{*}{ Pelatihan } & Menqikuti & 51 & 44,3 & 7 & 6,1 & 1 & 0,9 & 59 & 51,3 & 0,150 & \\
\hline & Tidak & 54 & 47 & 2 & 1,7 & 0 & 0 & 56 & 48,7 & & \\
\hline & Total & 105 & 91,3 & 9 & 7,8 & 1 & 0,9 & 115 & 100 & & \\
\hline${ }^{*}$ Lama & $6-12$ bulan & 1 & 0,9 & 0 & 0 & 0 & 0 & 1 & 0,9 & 0,016 & 0,225 \\
\hline \multirow[t]{5}{*}{ Kerja } & 1-3tahun & 7 & 6,1 & 0 & 0 & 0 & 0 & 7 & 6,1 & & \\
\hline & 3-5 tahun & 13 & 11,3 & 0 & 0 & 0 & 0 & 13 & 11,3 & & \\
\hline & 5-10 tahun & 35 & 30,4 & 2 & 1,7 & 1 & 0,9 & 38 & 33 & & \\
\hline & $>10$ tahun & 49 & 42,6 & 7 & 6,1 & 0 & 0 & 56 & 48,7 & & \\
\hline & Total & 105 & 91,3 & 9 & 7,8 & 1 & 0,9 & 115 & 100 & & \\
\hline Jenjang & PK 1 & 48 & 41,7 & 3 & 2,6 & 0 & 0 & 51 & 44,3 & 0,202 & 0,120 \\
\hline \multirow[t]{4}{*}{ Kerja } & PK 2 & 35 & 30,4 & 4 & 3,5 & 1 & 0,9 & 40 & 34,8 & & \\
\hline & PK 3 & 21 & 18,3 & 2 & 1,7 & 0 & 0 & 23 & 20 & & \\
\hline & PK 4 & 1 & 0,9 & 0 & 0 & 0 & 0 & 1 & 0,9 & & \\
\hline & Total & 105 & 91,3 & 9 & 7,8 & 1 & 0,9 & 115 & 100 & & \\
\hline
\end{tabular}

Keterangan :

${ }^{*} p$ value $<0,05$ yang berarti Berhubungan

Tabel 3 Hasil analisis multivariat determinan faktor yang berhubungan dengan pengetahuan perawat dalam perawatan paliatif di RSUD Dr. Soetomo Variabel Variabel

Std. Error Wald $p$-value 


\begin{tabular}{ccccc}
\hline Dependen & Independen & & & \\
\hline Pengetahuan & **Usia & 0,130 & 5,99 & 0,014 \\
\cline { 2 - 5 } $\begin{array}{c}\text { perawat } \\
\text { dalam }\end{array}$ & Penddikan & 1,887 & 1,019 & 0,313 \\
\cline { 2 - 5 } perawatan & Pengalaman & 3,85 & 3,374 & 0,066 \\
paliatif & Pelatihan & & \\
\cline { 2 - 5 } & *Lama Bekerja & 0,127 & 4,613 & 0,032 \\
\cline { 2 - 5 } & Jenjang Kariir & 0,508 & 1,288 & 0,256 \\
\hline
\end{tabular}

Keterangan :

${ }^{*} p$ value $<0,05$ yang berarti Berhubungan

${ }^{* \star} p$ value $<0,05$ yang hasilnya paling kecil diantara yang lain dan merupakan faktor paling dominan

Berdasarkan tabel 3 dapat diketahui bahwa variabel usia sebesar 5,99 dengan $p=0,014(<0,05)$, variabel pendidikan sebesar 1,019 dengan $p=$ $0,313(>0,05)$, variabel pengalaman pelatihan sebesar 3,374 dengan $p=$ $0,066(>0,05)$, variabel lama bekerja sebesar 4,613 dengan $p=0,032$ $(<0,05)$, dan variabel jenjang karir sebesar 1,288 dengan $\mathrm{p}=0,256$ $(>0,05)$. Hal ini menunjukkan bahwa variabel usia memiliki hubungan yang paling kuat dengan pengetahuan perawat dalam perawatan paliatif di RSUD Dr. Soetomo.

\section{PEMBAHASAN}

Pembahasan dalam penelitian ini disajikan dalam bentuk narasi dari hasil penelitian yang dilakukan oleh peneliti. Pada pembahasan ini diuraikan tentang faktor-faktor yang berhubungan maupun tidak berhubungan dengan pengetahuan perawat dalam perawatan paliatif.

\subsection{Usia Dengan Pengetahuan Perawat Dalam Perawatan Paliatif}

Pada penelitian ini mayoritas responden berusia 26-35 tahun. Hal ini sejalan dengan penelitian yang dilakukan oleh Abudari et al., dengan judul "Knowledge of and Attitude Palliative Care among Multinational Nurses in Saudi Arabia" yang menyatakan bahwa usia berhubungan dengan pengetahuan perawat dalam perawatan paliatif ${ }^{[9]}$.

Usia seseorang akan mempengaruhi kemampuan seseorang dalam menerima informasi dan pola pikir untuk menerima informasi yang diberikan. Semakin bertambahnya usia seseorang maka akan berkembang pula kemampuan untuk menerima informasi dan pola pikir. Kemampuan tersebut berhubungan dengan maturitas dari fungsi tubuh, baik indera maupun otak dan kesehatan seseorang ${ }^{[10]}$. Selain itu semakin cukup usia maka semakin matang pula tingkat kematangan dan kekuatan seseorang dalam hal berfikir dan bekerja ${ }^{[11]}$. Sehingga pada usia ini memiliki pengaruh terhadap tingkat pengetahuan individu.

Data distribusi menunjukkan bahwa terdapat sembilan responden yang memiliki pengetahuan cukup. Mayoritas responden memiliki pengetahuan yang baik dalam aspek manajemen nyeri dan gejala lainnya yang terkait dengan kondisi paliatif. Hal ini dapat diakibatkan karena seringnya responden merawat pasien paliatif yang merasa nyeri dan kemudian akan berpengaruh terhadap pengetahuan perawat yang terus bertambah. Dari data tersebut dapat diketahui bahwa kematangan usia dapat mempengaruhi pengetahuan.

\subsection{Pendidikan Dengan Pengetahuan Perawat Dalam Perawatan Paliatif}

Hasil penelitian menunjukkan bahwa tidak ada hubungan antara pendidikan dengan pengetahuan perawat dalam perawatan paliatif. Dalam penelitian ini menunjukkan bahwa setiap perawat yang menjadi responden mayoritas berpendidikan D3 sebanyak 65 perawat $(56,5 \%)$. Hal ini dikarenakan perawat yang diteliti yaitu perawat pelaksana.Hal ini sejalan dengan peneletian Morsy, Elfeky \& Mohammaed dengan judul "Nurses' Knowledge and Practices about Palliative Care among Cancer Patient in a University Hospital" didapatkan hasil bahwa perawat yang mendominasi yakni pendidikan D3 dan sebagai perawat pelaksana $^{[12]}$. 
Pendidikan dapat memberikan informasi dan membantu perawat dalam meningkatkan kemampuan serta lebih percaya diri dalam memberikan asuhan keperawatan ${ }^{[13]}$. Perawat yang ikut serta dalam program pendidikan lanjutan tentang perawatan paliatif bertujuan agar nantinya dapat meningkatkan pengetahuannya dan kualitas hidup pasien $^{[12]}$.

Selain itu masih ada faktor-faktor lain yang berhubungan dengan pengetahuan. Sebagaimana menurut Notoatmodjo dalam bukunya yang berjudul :Promosi Kesehatan dan Perilaku Kesehatan" menyatakan bahwa pengetahuan berhubungan dengan banyak faktor, seperti faktor internal (kesehatan, intelegensi, perhaatian, dan minal) serta faktor eksternal (keluarga, metode pembelajaran dan masyarakat) [9]. Pengetahuan juga dapat berhubungan dengan tingkat pendidikan, informasi, budaya, pengalaman dan sosial ekonomi. Usia dan pekerjaan individu juga dapat berhubungan ${ }^{[14]}$. Sehingga dapat disimpulkan bahwa belum berarti seseorang yang berpendidikan tinggi mutlak berpengetahuan tinggi pula, karena banyak faktor yang berhubungan dengan pengetahuan perawat tersebut.

\subsection{Pengalaman Mengikuti Pelatihan Dengan Pengetahuan Perawat Dalam Perawatan Paliatif}

Hasil penelitian menunjukkan bahwa tidak terdapat hubungan mengikuti pelatihan terhadap pengetahuan perawat dalam perawatan paliatif. Hal ini juga selaras dengan penelitian yang dilakukan Turangan, Kumaat \& Malara dengan judul "Faktor-faktor yang Berhubungan dengan Pengetahuan Perawat Dalam Menghadapi Cardiac Arrest di RSUP Prof R. D. Kandou Manado" menunjukkan bahwa tidak terdapat hubungan antara pelatihan dan pengetahuan perawat, dikarenakan terdapat responden yang telah mengikuti pelatihan lanjutan dan memiliki pengetahuan yang cukup disebabkan oleh responden yang kurang melakukan tindakan pertolongan pada klien cardiac arrest serta kurangnya motivasi ketika mengikuti pelatihan ${ }^{[15]}$.
Pelatihan merupakan serangkaian aktivitas individu yang dilakukan untuk meningkatkan keahlian dan pengetahuan secara sistematis, sehingga diharapkan memiliki kinerja yang profesional di bidangnya ${ }^{[16]}$. Pelatihan perawatan paliatif dapat memberikan kontribusi pada pengetahuan dan wawasan perawat ${ }^{[17]}$.

\subsection{Lama Bekerja Dengan Pengetahuan Perawat Dalam Perawatan Paliatif}

Hasil penelitian ini menunjukkan bahwa terdapat hubungan antara lama bekerja dan pengetahuan perawat dalam perawatan paliatif. Mayoritas responden sebanyak 56 perawat memiliki masa kerja lebih dari 10 tahun.

Sama halnya dengan penelitian yang dilakukan Morsy, Elfeky \& Mohammaed dengan judul 'Nurses' Knowledge and Practices about Palliative Care among Cancer Patient in a University Hospital" yang menyatakan bahwa responden memiliki lama bekerja lebih dari 10 tahun dalam merawat pasien kanker ${ }^{[12]}$. Hal ini didukung dengan penelitian yang dilakukan Burns \& Grove dengan judul "The Practice of Nursing Research Conduct, Critique, and Utilization" menyatakan bahwa perawat yang melakukan perawatan paliatif adalah perawat yang mahir dibidangnya ${ }^{[18]}$

Lama kerja identik dengan pengalaman, semakin lama masa kerja seseorang maka pengalamannya menjadi semakin bertambah. Pengalaman akan berpengaruh dalam meningkatkan pengetahuan seseorang, karena pengetahuan seseorang juga diperoleh dari pengalaman ${ }^{[19]}$. Lama kerja dapat memberikan pengaruh pada seorang perawat dalam pengetahuan dan memberikan perawatan paliatif ${ }^{[20]}$. Kriteria perawat yang memberikan perawatan paliatif adalah perawat yang berpendidikan minimal Diploma 3 dan telah mengikuti pelatihan perawatan paliatif $^{[5]}$.

Perawat yang memiliki masa kerja lebih lama akan mempengaruhi pengetahuan yang dimilikinya. Selain itu lamanya masa kerja juga akan memberikan informasi-informasi baru. 
Sehingga masa kerja yang semakin lama akan membuat pengetahuan perawat semakin bertambahkan dan semakin baik dalam membuat asuhan keperawatan.

\subsection{Jenjang Karir Dengan Pengetahuan Perawat Dalam Perawatan Paliatif}

Hasil penelitian didapatkan bahwa jenjang karir tidak berhubungan dengan pengetahuan perawat dalam perawatan paliatif. Jenjang karir perawat dapat dicapai melalui pendidikan formal dan pendidikan berkelanjutan berbasis kompetensi serta pengalaman kerja di sarana kesehatan ${ }^{[21]}$. Penerapan sistem jenjang karir merupakan salah satu solusi yang dapat diterapkan untuk menghindari kebosanan dan indiferensi pekerjaan. Kebosanan dalam pekerjaan terbukti dapat meningkatkan terjadinya pemutusan kerja sejalan dengan waktu dan pekerjaan yang sama ${ }^{[22]}$.

Jenjang karir tidak berpengaruh terhadap pengetahuan dikarenakan faktor lama bekerja dan masih kurangnya perawat mengikuti pelatihan mengenai perawatan palitif. Sehingga untuk mencapai sistem jenjang karir profesional diharapkan perawat meningkatkan pengetahuan sesuai dengan kompetensinya dan pihak rumah sakit juga memberikan penghargaan yang sesuai dengan level dan katagorinya.

\subsection{Usia Sebagai Faktor Dominan Dalam Pengetahuan Perawat Dalam Perawatan Paliatif}

Hasil penelitian menunjukkan bahwa faktor usia menjadi faktor yang paling dominan dengan pengetahuan perawat dalam perawatan paliatif di RSUD Dr. Soetomo. Data distribusi menunjukkan bahwa mayoritas responden berada pada rentang usia 26-35 tahun.

Usia 26-35 tahun merupakan usia dalam kategori dewasa awal ${ }^{[21]}$. Semakin bertambahnya usia seseorang maka kematangan seseorang dalam berpikir juga semakin meningkat. Bertambahnya usia seseorang dapat berpengaruh pada pertambahan pengetahuan yang diperoleh. Tetapi, adanya faktor fisik yang dapat menghambat proses belajar pada orang dewasa, dapat membuat penurunan pada suatu waktu dalam kekuatan berfikir dan bekerja. Sehingga, melalui pengetahuan yang telah dimiliki sebelumnya, pengalamansendiri, pengalaman orang lain, lingkungan dan faktor intrinsik lainnya dapat membentuk pengetahuan seseorang dalam jangka waktu yang lama dan akan tetap bertahan sampai tua ${ }^{[23]}$.

Pengetahuan responden tentang perawatan paliatif paling banyak mengerti pada aspek psikososial perawatan EOL. Hal ini terjadi karena perawat telah memiliki pengalaman dalam merawat pasien dan mendapatkan ilmu dalam masa perkuliahan maupun saat mengikuti pelatihan. Semakin tua usia responden maka pengalaman perawat dalam merawat pasien semakin banyak sehingga perawat memiliki banyak pengetahuan. Selain itu mayoritas perawat sedang berada pada usia produktif yaitu usia dimana seseorang sedang dalam masa ingin mengerti, sehingga perawat ingin tau dan mencoba mengerti segala sesuatu yang berhubungan dengan penyakit ataupun hal lain tentang pasien.

\section{KESIMPULAN}

Dari hasil penelitian dapat dilihat bahwa usia dan lama bekerja berhubungan dengan pengetahuan perawat dalam perawatan paliatif. Hal ini dikarenakan mayoritas usia perawat berada dalam kategori usia produktif, dimana pada usia tersebut seseorang memiliki kemampuan kognitif yang baik. Selain itu lama bekerja dan jenjang karir juga berhubungan dengan sikap perawat dalam perawatan paliatif. Semakin lama masa kerja perawat maka pengalaman dan pengetahuannya akan bertambah serta memiliki sikap yang lebih baik. Jenjang karir juga ditentukan oleh lama bekerja seseorang. Perawat yang memiliki jenjang karir tinggi harus memiliki sikap yang baik dalam merawat pasien sesuai dengan kompetensi yang dimiliki.

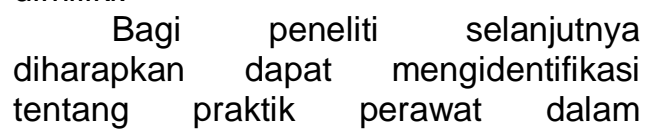


melaksanakan perawatan paliatif serta dengan jumlah responden yang lebih banyak.

\section{DAFTAR PUSTAKA}

1. Alliance, W. (2014) 'World Health Organization. Global Atlas of Palliative Care at the End of Life', London, England: Worldwide Palliative Care Alliance.

2. Baxter, S. et al. (2014) 'Global Atlas of Palliative Care at the End of Life', Worldwide Palliative Care Aliance. Available at: https://www.who.int/nmh/Global_Atl as_of_Palliative_Care.pdf.

3. World Health Organization (WHO) (2018) Palliative Care. Available at: https://www.who.int/newsroom/fact-sheets/detail/palliativecare.

4. Kemenkes, R. (2018) Potret Sehat Indonesia Dari Riskesdas. Available at: http://www.depkes.go.id/pdf.php?id $=18110200003$.

5. Tejawinata, S. and Razak, A. (2012) Surabaya Kota Paliatif: Citra dan Pesonanya. Surabaya: RSUD Dr. Soetomo.

6. Uslu-Sahan, F. and Terzioglu, F. (2017) 'Nurses' Knowledge and Practice toward Gynecologic Oncology Palliative Care', Journal of Palliative Care and Medicine, 7(4). doi: 10.4172/21657386.1000315.

7. Dewati, A. and Irdawati (2013) 'Hubungan Antara Pengetahuan dengan Perilaku lbu dalam Pemenuhan Kebutuhan Nutrisi Anak Batita Malnutrisi di Posyandu Desa Sembungan Boyolali', Jurnal Keperawatan Prosiding Seminar IImiah Nasional Kesehatan.

8. Arikunto, S. (2013) Prosedur Penelitian: Suatu Pendekatan Praktik. Jakarta: Rineka Cipta

9. Abudari, G. et al. (2014) 'Knowledge of and Attitude Palliative Care among Multinational Nurses in Saudi Arabia', International Journal of Palliative Nursing, 20(9), pp. 435-441. doi: 10.12968/ijpn.2014.20.9.435.

10. Notoatmodjo, S. (2012) Promosi
Kesehatan dan Perilaku Kesehatan. Jakarta: Rineka Cipta.

11. Wawan, A. and Dewi, M. (2010) Teori dan Pengukuran Pengetahuan, Sikap dan Perilaku Manusia. Yogyakarta: Nuha Medika.

12. Morsy, W. Y. M., Elfeky, H. A. and Mohammaed, S. E. (2014) 'Nurses' Knowledge and Practices about Palliative Care among Cancer Patient in a University Hospital Egypt', Advances in Life Science and Technology, 24, pp. 100-113.

13. El-Nagar, S. and Lawend, J. (2013) 'Impact of Palliative Care Education on Nurses' Knowledge, Attitude and Experience Regarding Care of Chronically III Children', Journal of Natural Science Research, 3(11), pp. 94-103.

14. Asrofudin (2010) Faktor-faktor yang Mempengaruhi Pengetahuan. Available at: http://www.canboyz.co.cc.

15. Turangan, T., Kumaat, L. and Malara, R. (2017) 'Faktor-faktor yang Berhubungan dengan Pengetahuan Perawat Dalam Menghadapi Cardiac Arrest di RSUP Prof R. D. Kandou Manado', E-Journal Keperawatan(e-Kp), 5(1).

16. Widodo (2016) 'Faktor-faktor yang Berhubungan Dengan Pengetahuan Perawat Tentang Penatalaksanaan Asuhan Keperawatan Pasien Dekompensasi Kordis di Ruang ICVCU RSUD Dr. Moewardi', Jurnal Keperawatan Global, 1(2), pp. 55-63.

17. Andriaansen (2005) Effects of a Postqualification Course in Palliative Care. University of Professional Education.

18. Burns, N. and Grove, S. (2005) 'The Practice of Nursing Research Conduct, Critique, and Utilization (5th edition)', in. St. Louis: Elsevier Saunders.

19. Wibowo, A., Suryani, M. and Sayono (2013) 'Hubungan Karakteristik Perawat Dengan Penggunaan Sarung Tangan Pada Tindakan Invasif di Ruang Rawat 
E - ISSN : $2722-127 X$

$P$ - ISSN : $2338-4700$

Inap RSUD Dr. H. Soewondo Kendal', Jurnal IImu Keperawatan dan Kebidanan, 1(4), pp. 1-9.

20. Giarti, A. T. (2018) Gambaran Pengetahuan Perawat Tentang Perawatan Paliatif Pada Pasien Kanker di RSUD Dr. Moewardi. Universitas Muhammadiyah Surakarta.

21. Direktorat Bina Pelayanan Keperawatan Departemen Kesehatan Republik Indonesia (2006) Pedoman Pengembangan Jenjang Karir Profesional Perawat.

22. Marquis and Huston (2010) 'Kepemimpinan dan Manajemen Keperawatan, Teori dan Aplikasi. Alih Bahasa: Widyawati dan Handayani', in. Jakarta: BGC.

23. Warawirasmi, T. (2014) Faktorfaktor yang Mempengaruhi Pengetahuan Perawat Tentang Catether-Associatied Urinary tract Infections di Intensive Care Unit. Universitas Diponegoro. 